\title{
sciendo
}

DOI: 10.2478/orga-2020-0005

\section{Conceptual Key Competency Model for Smart Factories in Production Processes}

\author{
Andrej JERMAN ${ }^{1}$, Andrej BERTONCELJ ${ }^{1}$, \\ Gandolfo DOMINICl${ }^{2}$, Mirjana PEJIĆ BACH ${ }^{3}$, \\ Anita TRNAVČEVIĆ ${ }^{1}$
}

\begin{abstract}
${ }^{1}$ University of Primorska, Faculty of Management, Koper, Slovenia, andrejjerman1@gmail.com, andrej.bertoncelj@ fm-kp.si, anita.trnavcevic@fm-kp.si

²University of Palermo, Dep. SEAS, Polytechnic School, Palermo, Italy, gandolfo.dominici@libero.it

3University of Zagreb, Faculty of Economics and Business, Zagreb, Croatia, mpejic@net.efzg.hr
\end{abstract}

\begin{abstract}
Background and Purpose: The aim of the study is to develop a conceptual key competency model for smart factories in production processes, focused on the automotive industry, as innovation and continuous development in this industry are at the forefront and represent the key to its long-term success.

Methodology: For the purpose of the research, we used a semi-structured interview as a method of data collection. Participants were segmented into three homogeneous groups, which are industry experts, university professors and secondary education teachers, and government experts. In order to analyse the qualitative data, we used the method of content analysis.

Results: Based on the analysis of the data collected by structured interviews, we identified the key competencies that workers in smart factories in the automotive industry will need. The key competencies are technical skills, ICT skills, innovation and creativity, openness to learning, ability to accept and adapt to change, and various soft skills. Conclusion: Our research provides insights for managers working in organisations that are transformed by Industry 4.0. For instance, human resource managers can use our results to study what competencies potential candidates need to perform well on the job, particularly in regards to planning future job profiles in regards related to production processes. Moreover, they can design competency models in a way that is coherent with the trends of Industry 4.0. Educational policy makers should design curricula that develop mentioned competencies. In the future, the results presented here can be compared and contrasted with findings obtained by applying other empirical methods.
\end{abstract}

Keywords: competencies, conceptual key competency model, smart factory, Industry 4.0, automotive industry

\section{Introduction}

Recent technological developments, such as sensors, cyber systems, the Internet of Things and smart networks, will affect every area of our lives. This development is called the "fourth industrial revolution" (Gilchrist, 2016), also known as "Industrie 4.0" or "Industry 4.0", "smart manufacturing", "industrial internet" or "integrated industry" (Hofmann \& Rüsch, 2017). Germany was the first to use the phrase in 2011 and referred to it as a high-tech strategy for industry (Mosconi, 2014; Prifti et al., 2017) and the Internet of Things (IoT), Internet of Services (IoS), cyber-physical systems, blockchain technologies, big data and hyperconnectivity (Hitpass \& Astudillo, 2019).

An important aspect of Industry 4.0 is robotics, which incorporates mechatronics and computing systems, whereby machines can process data and communicate with other machines or humans, through a wireless network known as the Internet of Things (IoT) (Nader, Jameela, \& Jawhar, 2008; Roblek, Meško, \& Krapež, 2016). For this reason, many companies have connected several kinds of "smart" sensors with different digital devices (Arsenijević et al., 2019). These machines will both generate and col-

Received: August 30, 2019; revised: January 2, 2020; accepted: February 7, 2020 
lect data, which with the addition of artificial intelligence could mean that humans will no longer be needed to carry out repetitive and simple tasks. This would be due to machines being able to carry out all of these tasks more efficiently (Rifkin, 1995; Kane et al., 2015; Hungerland et al., 2015; World Economic Forum, 2018).

Industry 4.0 has already revolutionized the supply chain, among other things, as real-time sensing and transfer of data, combined with the computational capabilities of machine learning algorithms. This has enabled advanced planning and scheduling of cyber-physical systems (CPS), as well as customer relationship management (CRM) and enterprise resource planning (ERP) systems (Govindan et al., 2018; Lai et al., 2018). These smart upgrades to the supply chain have already shown positive results in regards to tracking commodity flow, monitoring data concerning warehouse and store inventories, gathering data about orders for items, delivery reliability and customer satisfaction (Brettel et al., 2014; Kache et al., 2015). Technologies will not only be used for working with machinery, but will also be used for integrated product and service offerings focused on customer satisfaction (Lee, Kao, \& Yang, 2014, Lee et al., 2015).

Industry 4.0 will have significant impact on our working environments (Bagnoli et al., 2019) by transforming manufacturing, sales, maintenance work and the process of purchasing from an organisation. This will occur because of the implementation of smart manufacturing and maintenance systems with high levels of integration and automation with different automation solutions such as Robotic Process Automation (Šimek \& Šperka, 2019).Smart systems will also be present in various kinds of business processes that are not directly related to manufacturing (Kompetenzaufbau, 2016). This will have far-reaching implications for the creation of business value, business models, further services, and the organisation of work (Kagermann et al., 2013; Bertoncel et al., 2018). Consequently, employees will face work processes and business models that have been reshaped, as well as new technologies for day-to-day tasks (Kompetenzaufbau, 2019). The model of work organisation will be transformed by the disruptive nature of emerging technologies and changed structures for communication and collaboration (Zinn, 2015).

The Industry 4.0 market will grow from 66.67 billion USD in 2016 to 152.31 billion USD or even as much as 214 billion USD in 2022; by 2030, it has been predicted to grow to as high a value as 1 trillion USD (MarketsAndResearch, 2017; Wood, 2018). If the predicted exponential growth turns out to be accurate, then the number of required personnel in the industry will increase, driving the need for HR professionals, managers, and other decision-makers. In order to attract such experts, human resources professionals should be well versed in the terminology of Industry 4.0 and methods for finding the perfect candidates for the new jobs.
Because of the aforementioned fast-paced technological changes occurring in industry, many educational programs and workers will not provide the necessary competencies required for the upcoming needs. That will force production organisations to increase flexibility, efficiency and quality (Zhang et al., 2017), as well as the creation of new employee structures, qualifications, and competencies (Kane et al., 2015; Macurova et al., 2017). For this reason, we have raised the following research questions:

RQ1: According to the interpretation of the participants of the study, what is the expected change in the competencies that will be needed in the production processes at the automotive smart factory in the future (by 2030)?

RQ2: What key competencies do employees need to develop for the successful introduction of smart factories in the automotive industry?

It is important to know and understand new competencies of employees introduced by the concept of Industry 4.0. This is especially true for the automotive industry, which is among the most prominent sectors of Industry 4.0. As part of the qualitative research, we focused on identifying the key competencies of employees in production processes, which will play a key role in bridging the gap between existing (established) production process management concepts and a new paradigm for managing high technology processes, within the framework of Industry 4.0. Technological developments and other changes in the environment bring about crucial changes in this field as well and play a key role in the progress (Enke et al., 2018). Prioritizing the transformation of classic factories into smart factories is to determine the new competencies of employees.

The aim of this study was also the development of a conceptual model of key competencies in production processes, which will enable a more efficient and effective introduction of changes in the field of human resources in smart factories in the automotive industry.

\section{Literature review}

Numerous research disciplines, including psychology, education, organisational management, human resources, and information systems, have examined the concept of competencies (Prifti et al., 2017), in an environment of knowledge economy (Ženko et al., 2017). The first definition of competency was given by McClelland (1973), who defined it as "a personal characteristic or set of habits leading to more effective or better performance". A definition of competency that is more comprehensive and more frequently used was formulated by Spencer and Spencer (1993, 9): "competency is an underlying characteristic of an individual that is causally related to criterion-referenced effective and/or superior performance in a job or situation".

Competency studies are mostly following one of three 
approaches that were developed independently (Le Deist \& Winterton, 2005). The behavioural approach focuses on attributes that go beyond cognitive abilities, such as self-awareness, self-regulation, and social skills (McClelland, 1973; Boyatzis, 1982). This approach argues that competencies are essentially behavioural, unlike personality or intelligence, and that they can be learned through education and development. The functional approach focuses on competencies as requirements for successful completion of the task by limiting the competency mandate to the skills and knowledge required to perform the task (Frank, 1991;). An integrated/multidimensional approach describes competencies as a collection of specific competencies that the individual needs and the organisational skills required at the organisation level to achieve the desired results (Straka, 2004).

Competencies can be defined as the sum of knowledge, skills, and experience that a person can use in the event of a new or unexpected situation (Kauffeld, 2016). It is situation-dependent behaviour, seen in the moment and by the response of an individual through his social context (Kauffeld, 2016). The most important is that competencies are variable and that they allow an employee to contribute actively to the new and complex tasks, for example, in the didactic concept in higher education systems (Kauffeld, 2006; Erpenbeck \& Von Rosenstiel, 2007). Daily (working) life competencies are needed to search for solutions in unprecedented situations autonomously. In terms of work, competencies can be divided into four main categories: professional competencies (e.g., knowledge of processes), methodological competencies (e.g., techniques for structuring themselves), and social competencies (e.g., socially relevant behaviour in interactions) and personal competencies (e.g., strategies for self-control, e.g., self-reflection) (Erpenbeck \& Von Rosenstiel, 2007).

Key competencies are competencies that are important for an individual in different areas of life (Rychen \& Salganik, 2003). These competencies are not domain-specific, but they represent a broader context of a set of skills, understanding, knowledge and personal characteristics that have been proved important (Barth et al., 2007; Kotzab et al., 2018). Key competencies largely extend responsibility to enable continuous learning of other specific competencies (Leoni, 2012).

Competencies play an important role in the development of appropriate skills, understanding, knowledge, and personal characteristics, which allow the employee to achieve the desired results. To adapt to rapid changes and increased need for creativity, the competencies that individuals acquire through traditional education are no longer sufficient. For this reason, the need to determine the key competencies of employees is necessary. There are quite a few reasons for studying key competencies. As an example, Boštjančič $(2011,25)$ states that, by determining key competencies, it is possible to formulate criteria for individual jobs, which fully reflect the actual skill needs of the job. This can be done by determining the competencies required for particular jobs, as well as facilitating the recognition of individual characteristics of personnel and their impact on work efficiency and performance. In addition, managers in production organisations can more easily manage the risks that occur during the transition, if they recognize the necessary competencies of staff at the factories of the future in sufficient time (Kremer, 2014).

Some researchers have identified competencies that will be relevant in the future. Some of the findings are listed below. According to Prifti et al. (2017), 68 competencies are important for Industry 4.0: deciding and initiating action, leading and supervising, working with people, adhering to principles and values, relating and networking, persuading and influencing, presenting and communicating information, writing and reporting, applying expertise and technology, analysing, learning and researching, creating and innovating, formulating strategies and concepts, planning and organizing, delivering results and meeting customer expectations, following instructions and procedures, adapting and responding to change, persuading and influencing, achieving personal work goals and objectives, and entrepreneurial and commercial thinking. According to Erol et al. (2016), competencies of the future are lifelong dedication to learning, social, personal, decision-making and leadership competencies that involve complex interaction within a society as a whole, individual groups within that society and the work environment, as well as competencies that allow for a critical perspective on technological progress and research. Other competencies include a thorough understanding of the software and hardware components of upcoming and existing technology, in regards to manufacturing and other practical applications, as well as an ability to use this understanding in practice, for example, practical experience using various machine-learning algorithms (Erol et al., 2016). Hecklau et al. (2017) published another research with an overview and analysis of twelve studies of employees' competencies needed for Industry 4.0. They found out that the most critical competencies are communication and cooperation (especially working in business ecosystems on virtual platforms), coding competence (IT competence), complex problem solving, process understanding, interdisciplinary competence, and creativity.

Modern business conditions pose challenges for employees, as they are constantly pressured to improve work performance and work results. Due to constant changes in the market and in the environment, competency profiles are quickly outdated, resulting in a need for a partial or full revision of a competency model.

The competency model consists of the desired competencies for a specific task and may include a description of individual competencies (Markus, Cooper-Thomas, \& Allpress, 2005). These lists may contain different levels of detail and describe the relationship between competencies. 
Many competency models have been developed over the years. For example, Erpenbeck and Rosenstiel (2007) offer a model with the separation of competencies into four categories: personal, social/interpersonal, fact-related, and domain competencies. Nippa and Egeling (2009) use the second classification by separating competencies into the meta, domain, method, and social competencies.

A competency model, according to CEB Inc. (as it has been formally known SHL) company's universal competency framework (CEB SHL UCF), offers a universal framework of competencies and is based on a variety of competitive approaches from research and practice. It offers a behavioural approach to modelling competencies by focusing on an individual and taking into account the competencies of a behavioural nature, which means that an individual can learn and accept them and is not based on personality. As a framework, it provides a structure and overview of competencies by integrating them into descriptive categories. This framework can be used to develop competency models that represent a descriptive and simplified view of competencies as a specific phenomenon that needs to be analysed. SHL UCF is widely used in practice, and many companies use it to describe their competency models for specific jobs and it is composed of three hierarchical levels: the "Big Eight", the dimension of competencies and competency constraints (Prifti et al., 2017).

Pecina and Sladek (2017) find that one of the critical issues to be considered within Industry 4.0 and smart factories is the analysis of workers' competencies. Similarly, Imran and Kantola (2019) consider it crucial to determine the competencies for new job profiles at factories. Thus far, the technical aspect of development has been discussed in the subject of Industry 4.0, as well as smart factories, and the field of management and "soft factors" is very. This aspect is neglected primarily in the field of scientific research, but is increasingly dealt with in reports by leading consultants, such as McKinsey, Deloitte, Accenture, and the Boston Consulting Group (Vacek, 2016).

The research is focused on understanding and exploring the key competencies in Industry 4.0. After the review of research literature, key competencies for Industry 4.0 were perceived as a rather unexplored area and worthy of in-depth scientific analysis. Research on this topic is scarce and is based mainly on secondary sources, while empirical research is rare.

\section{Methodology}

The research uses qualitative methods to inquire about the perceived relevant competencies of Industry 4.0 job profiles, specifically within the automotive sector. The purpose of this research is not to measure phenomenon occurring at automotive smart factories or to replicate results or generalize them. Instead, the purpose is that of social constructivism, where 'social constructions' are seen as power relations, marginalized groups, understandings, interpretations and meanings, among other things, are at the core of such research. Creswell (2007), and Caelli, Ray and Mill (2003) talk more in-depth about the differences of ontological and epistemological assumptions when talking about the similarities and differences of qualitative and quantitative research. Creswell (2007) also presents five main traditions, from case studies to grounded theories.

The automotive industry is one of the largest and most important industry in the world. Bilas, Franc and Arbanas (2013) mention that on an economic scale, according to OICA (French: Organisation internationale des constructeurs d'automobiles), the automotive industry could be considered the world's sixth largest economy. Innovative technological development and advanced technologies are key in the automotive industry's success and ability to be able to provide approximately one in nine jobs in developed countries, while also being one of the largest employers worldwide. The automotive market is becoming increasingly global, whereby changes throughout the world, regardless of the country of origin, are dictating new guidelines, rates of operation and supply chains (Erenda et al., 2018). The automotive industry in Slovenia contributed 10 percent of GDP and employs more than 24,000 people. Most robots in the industry are used in South Korea, especially in the automotive industry. Slovenia is one of the countries with a high share of robots in the automotive industry since last year, notes the International Society for Robotics (IFR) (Slovenska avtomobilska industrija vedno bolj robotizirana, 2019).

\subsection{Sample}

To achieve the goal of creating a conceptual model of key competencies, related to production processes in the Slovenian automotive industry, several interviews with experts were conducted. The research was carried out using the semi-structured interview method. To enhance the credibility of the qualitative interview method, data source triangulation was used, which enables a more comprehensive (broader) view of the problem under study (Vogrinc, 2008). This was done by including industry experts, university professors, and government experts.

As it is usually the case for exploratory studies, the sampling procedures lead to purposive or quota samples. In the case of this study, a purposive sample was designed, meaning that the research problems have been explored from the perspective of three key groups: policymakers, industry representatives and experts (university professors). These groups were identified as 'the most knowledgeable yet diverse informants' (Merriam, 2002)' who can provide in-depth insight into the research problem. These representatives/participants know about the topic the most. The first group was selected from the member- 
ship of ACS. Management at the ACS was asked which out of the 80 companies was most active and advanced factories in its field. We also added an additional criterion, where we looked for companies larger than 10 employees, because processes and business models differ because of the size of the company. For the selection of the participants in the second group, we looked at Cobiss data base to identify Slovenian researchers/professors who write on the topic. Perhaps the easiest selection was for a group of policymakers - people from the ministries etc., as we asked different ministries for the names and contacts of persons who are in charge of Industry 4.0 in a direct or indirect way. The general criterion for selection was; they need to be the most recognized people in their area.

Participants were segmented into three homogeneous groups (Galletta, 2013), which are:

- Industry experts (six participants) are senior executives involved in the projects of transforming traditional factories into smart factories. These executive must be employed at a large Slovenian manufacturing organisations, whose main activity is the automotive industry. In addition, they must be members of the Slovenian Automotive Cluster (ACS) and operate according to the Industry 4.0 paradigm.

- University professors and secondary education teachers, whose research and teaching is focused on the competencies and Industry 4.0 in general (within the framework of smart factories). The second group of participants in the study was composed of six experts. Three of them were from the business faculties from different universities in Slovenia and three of them from higher education institutions.

- Government experts employed at the Ministry of Economic Development and Technology, Ministry of Science, Education and Sports and the Ministry of Infrastructure. Three policy makers participated in the research and comprised the group of 'Governement experts'.

\subsection{Method of data collection}

For the purpose of the research, we used a semi-structured interview as a method of data collection. Interviewees explained the purpose and course of the research. Participants were asked about their perception of expected change in the competencies that will be needed in the production processes, and key competencies that will be needed by employees for the successful introduction of smart factories in the automotive industry. We recorded the interviews, made transcripts later, and further processed by content analysis. Interview lasted on average 45 minutes.

\subsection{Data analysis}

In order to analyse the qualitative data collected by indepth interviews, we used the method of content analysis, which is a well-established, empirically based method that allows the structuring of the qualitative data (in our example, the text of the transcripts of interviews of the participants of the research). The method of content analysis is a research method, more precisely an empirically based method, which is used mostly in social sciences (Neuendorf, 2016).

\section{Result and discussion}

The content analysis was started with the reduction or the regulation of data. Reduction levels were followed by the organisation and processing of data, which was an organised process of discovering the meaning of the text by selecting and combining data (terms and categories) that enabled conclusions and their presentation with the final phase (Lamut \& Macur, 2012). The data were coded by two researchers independently. In case that their coding was substantially different, a third researcher was involved in order to resolve disputes and hence increase inter- reliability of coding. Assigned codes are presented in Table 1.

Based on the experts' answers, it is possible to conclude that existing competencies will be upgraded with new knowledge, and will be developed in a wider and complex manner. Highly skilled workers will be needed, who will master increasingly complex tasks. New competencies will be focused more on the creativity and soft skills and a stronger accent to the integration of various skills and areas of expertise will be provided.

A structured analysis presented in Table 2 was conducted, in order to collect data needed to answer the second research question (RQ2). The aim was to identify the key competencies needed by employees for the successful operation of smart factories in the automotive industry. 
Table 1: Participants' opinions on changes in future competencies.

\begin{tabular}{|c|c|c|}
\hline Number & Selected quotations & Assigned code/ category \\
\hline Quotation 1 & $\begin{array}{l}\text { "Existing competencies will be upgraded with knowledge of ex- } \\
\text { isting and new technologies and competencies related to auto- } \\
\text { mation, data capture, and processing of these" }\end{array}$ & existing competencies will be upgraded \\
\hline Quotation 2 & $\begin{array}{l}\text { "Competencies will develop to become more complex and wider, } \\
\text { with emphasis on combining technical and communication } \\
\text { sciences. The creativity and the ability to exploit the high } \\
\text { potential of available technologies, the ability to critically look } \\
\text { at workable applications and find ideas for improvement will } \\
\text { also be challenging the leadership of highly educated, specialist } \\
\text { researchers, which will need to be combined into an effective } \\
\text { team with organisational skills and leadership skills, including } \\
\text { specialists in a particular field." }\end{array}$ & creativity and soft skills \\
\hline Quotation 3 & $\begin{array}{l}\text { "Workers will have to master information technology, use mod- } \\
\text { ern devices, and decide independently and quickly. The demand } \\
\text { will be for highly skilled workers who will master increasingly } \\
\text { complex tasks. The need for workers for simple work will be } \\
\text { reduced. It will also be important to master databases since } \\
\text { we will have access to ever-increasing amounts of data. The } \\
\text { needs for social skills, communication, leadership, coordina- } \\
\text { tion, creativity, and control of emotional intelligence will be } \\
\text { emphasized." }\end{array}$ & $\begin{array}{l}\text { integration of various skills and areas of } \\
\text { expertise }\end{array}$ \\
\hline Quotation 4 & "...that you are capable of learning and upgrade skills." & existing competencies will be upgraded \\
\hline Quotation 5 & $\begin{array}{l}\text { "Employees will have to be able to solve complex tasks and } \\
\text { upgrade their knowledge." }\end{array}$ & existing competencies will be upgraded \\
\hline Quotation 6 & $\begin{array}{l}\text { "More flexibility, ability to innovate and be creative will be } \\
\text { needed in the future." }\end{array}$ & creativity and soft skills \\
\hline Quotation 7 & $\begin{array}{l}\text { "The competencies of the future will differ from today's com- } \\
\text { petencies, and more emphasis will be placed on the innovation } \\
\text { and creativity, people will need to have more knowledge and be } \\
\text { able to be trained continuously and acquire new knowledge." }\end{array}$ & creativity and soft skills \\
\hline Quotation 8 & $\begin{array}{l}\text { "... because technology basically does not think, definitely cre- } \\
\text { ativity of employees will be important." }\end{array}$ & creativity and soft skills \\
\hline Quotation 9 & $\begin{array}{l}\text { "In any case, we should not ignore the fact that Industry } 5.0 \text { will } \\
\text { come to life by 2030, but it will be different from Industry } 4.0 . \\
\text { This industry introduces the so-called participating robots into } \\
\text { production processes. These are robots that will be technolog- } \\
\text { ically capable of working with people in production processes. } \\
\text { So it will be a so called communication with the machine." }\end{array}$ & communication with the machine \\
\hline Quotation 10 & $\begin{array}{l}\text { "The competencies of the future are unlikely to be much dif- } \\
\text { ferent from the competencies that are desirable now, but the } \\
\text { knowledge will change - something will be outdated, and a lot } \\
\text { will be new knowledge. And the fact that we are still learning } \\
\text { precisely certain knowledge in schools is bad-they should have } \\
\text { been taught to think, create, innovate, polemise ... These are } \\
\text { the competencies of the present and will be the competencies } \\
\text { of the future." }\end{array}$ & creativity and soft skills \\
\hline Quotation 11 & $\begin{array}{l}\text { "Basic competencies will include flexibility, open thinking of } \\
\text { employees, specialization in certain technical fields, and readi- } \\
\text { ness to innovate..." }\end{array}$ & creativity and soft skills \\
\hline Quotation 12 & $\begin{array}{l}\text { "In addition to a high level of technical knowledge, teamwork } \\
\text { competencies will be needed, rapid problem solving, respon- } \\
\text { siveness and adaptation to change will be in high demand, } \\
\text { which, in my opinion, will be even more intense..." }\end{array}$ & creativity and soft skills \\
\hline
\end{tabular}


Table 2: Key competencies identified by industry experts, university professors, and government experts.

\begin{tabular}{l} 
Group of experts / Sector \\
Ministry expert / Government \\
\hline Ministry expert / Government \\
Ministry expert / Government \\
Chamber of commerce / Government
\end{tabular}

University professor / Education

University professor/Education

University professor / Education

Secondary school professor/Education

Secondary school professor/Education
Key competencies

Flexibility, openness

Openness, programming

Technical skills

I am sure that an important profession in the automotive industry will become an engineer of the mechatronics car. These will be experts who will know about mechanical engineering, electronics, information technology, computer science, etc.

\section{Cooperation with robots}

Openness to learning (this is a very important characteristic) and paying attention to the signals from the environment

Technology literacy

In particular, competencies in the field of ICT, digital technologies, as well as coordination, management and monitoring of processes.

However, if I go back to the competencies to be developed, this is communication because of ICT technology, is moving or changing, and then the knowledge of foreign languages, the ability to solve problems, critical and analytical thinking, etc. is very important.
In particular, competencies in ICT, digital technologies, as well as coordination, management and monitoring of processes

Openness to change, multilingualism, technological competencies, knowledge of ICT technologies, use and sharing of technological devices, soft skills (leadership, motivation, understanding, etc.).

\begin{tabular}{ll}
\hline Automotive industry expert / Private & $\begin{array}{l}\text { They are all critical. The "mind" of the factory and its smartness } \\
\text { alone do not guarantee competitiveness. }\end{array}$ \\
\hline Automotive industry expert / Private & Technical knowledge \\
\hline Automotive industry expert /Private & Ability to accept and adapt to changes
\end{tabular}

Source: Authors work

The key competencies mentioned by the ministry participants of the study are technical skills, which include various technical knowledge, such as knowledge of ICT technologies, mechanical engineering, electronics, and computer science (such as programming), openness to changes, flexibility, curiosity, critical and analytical thinking, and multilingualism. The Chamber of commerce expert believes that within the automotive industry knowledge of mechatronics, i.e., knowledge of mechanical engineering, electronics, information technology, computer science will be key to becoming a mechatronic expert for car development. In addition, the government representatives believe that ICT skills will be needed in the upcoming fourth industrial revolution. This is reflected in the fact that that there will be an increase in machine operators, software maintenance, and hardware maintenance jobs in the future, all of which require programming and technical skills (Lorenz et al., 2015; Hecklau et al., 2016). While a decrease will be seen in repetitive, routine, and physically demanding jobs, in contrast, skill sets related to innovation and creativity, requiring flexibility and openness, such as openness to receiving a higher level of education, flexible responses, openness and flexibility in problem-solving, as well as openness to complexity, will increasingly be needed (Lorenz et al., 2015; Hecklau et al., 2016). This is also reflected in the answers we received from secondary education experts.

The educational organisations representatives believe that openness to learning is essential. In addition, they believe that cooperation with robots and technological literacy will be a key competency. This makes sense, as smart manufacturing will include the continuous information flow and exchange between humans and machines (C2M), while at other times with machine to machine communi- 
cation (M2M) (Cooper \& James, 2009; Greengard, 2015; Roblek et al., 2016). Experts in secondary education also concur those such competencies in ICT and digital technologies will be needed. These attitudes are also shared by the experts from the private sector. The management and monitoring of cyber-physical systems (ICT and digital technologies, i.e., the systems connecting real and virtual environments, which includes the use of the Internet of things) will play a critical role in a key competency profiles.

The private sector representatives also added that the ability to accept and adapt to change would be important. Segal (2018) states that some argue that the future will not be so much about jobs being lost or gained, so much as it will about the restructuring of jobs; employees will need to adapt to new technology, such as they have had to in the previous industrial revolutions. For those that cannot adapt to these changes, policies will need to be put in place so that those individuals can live decent lives. For those that believe that the pace of big data analysis and associated technologies is growing too quickly, policies can also help slow things down, in order to ease the stress, which will be encountered when the workforce will need to adapt to these new digital technologies.

Finally, various soft skills were mentioned by the private sector experts, who believes that skills other than technical will be important, as smart technology alone does not guarantee competitiveness. Some of the soft skills that were stated by the interviewees include multilingualism, leadership, motivation and understanding, and environmental awareness.

Based on the research results, we have developed a key competency model (Figure 1), which includes various sets of skills and personal characteristics. Two groups of competencies are identified: operational knowledge and personality characteristics. Operational knowledge is fostered by technical literacy, ICT literacy, innovation and creativity. On the other hand, personality characteristics relevant in Industry 4.0 environment are soft skills, openness to learning, and flexibility and adaptation to change. Key competencies were developed by experts from three sectors: the government, the education sector and the private sector. Education sector experts proposed two groups of competencies: openness to learning, and innovation and creativity. Government experts proposed three groups of skills: innovation and creativity, ICT literacy, and technical literacy. Private sector experts proposed two groups of skills: soft skills and flexibility / adaptation to change.

These results indicate that government experts are mostly oriented towards the improvement of productivity by the new technologies; education experts are mostly oriented towards new knowledge that could lead to creativity and innovation of services and products; and finally, the private sector experts are focused mostly on the characteristics that fosters workers' effectiveness, such as soft skills, and adaptation to change.

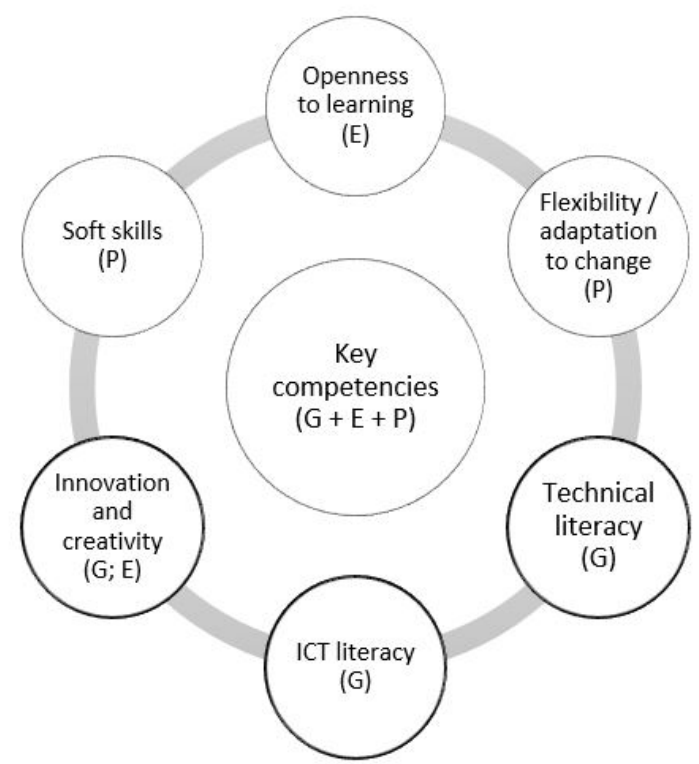

Figure 1: Conceptual key competency model

It is crucial for organisations to formulate an appropriate strategy to support their planning in relation to the upcoming development of Industry 4.0 (Ivanov et al., 2016). Strategic design requires an exhaustive strategic plan from organisations to visualize the steps towards a digital production organisation - a smart factory (Sarvari et al., 2018). Planning is an essential component of creating and delivering strategy and innovation in several organisations; therefore, in order to ensure success in the digital transformation process within Industry 4.0, a strategic transformation plan is indispensable (Vogel-Heuser \& Hess, 2016). Understanding the specific features of the transition to Industry 4.0 in the field of HR competencies is a prerequisite for the development of a strategic plan.

\section{Conclusion}

This research is an exploratory study into future competencies. There is no abundance of publications on this topic in relation to smart factories in the automotive industry, and the field, to our knowledge, has not been explored in Slovenia. Here we study the automotive industry, because it is a global industry, affected by a large number of competitive manufacturers striving to develop smart factories. To study the case, we chose the automotive industry in Slovenia. It is known that the countries with the greatest potential in Industry 4.0 (Germany, Singapore, South Korea and Japan) (Liu, 2019) also have a high degree of modernization in the manufacturing industry, but Slovenia, in the context of smart manufacturing research, is a Europe- 
an Union Member State with high industrial potential. It is economically tied to countries from the aforementioned group, with Germany at the head (Industry 4.0 and Europe 2017). This means that as a direct partner it participates in the development of Industry 4.0, as there are no borders to the business process model; companies (production organisations) tend to have branches, production and other organisational units outside the country of the holder of the production organisation. Slovenia has the advantage that, due to its high levels of education and technological advancement, it is highly represented in the automotive industry, which is far advanced in implementation of the Industry 4.0 philosophy. The Slovenian manufacturing organisations in the automotive industry, which were also included in our research, are the first to announce investments in the construction of their smart factories or are the winners of numerous awards for innovation.

Results of our study can be utilized by different stakeholders, i. e. top managers, HR professionals and secondary and higher education institutions policy makers. They could provide strategic managers in the manufacturing sector research a new strategic approach to introducing personnel changes needed for Industry 4.0 organisations.

A conceptual competencies model could provide human resource strategic managers with information about experts' opinions of future competencies needed to adapt to changes in production processes at manufacturing organisations. Educational policy makers should design curricula that develop competencies such as ICT literacy, and to cover activities that are needed to develop soft skills like innovation, creativity, openness to learning, and flexibility and adaptation to change.

The limitation of the study is not so much an issue of methodology, but has more to do with human bias. For example, qualitative data are collected with interviews with humans and analysed by humans, which can lead to different interpretations of the same data. As such a qualitative study is inherently biased from an analytical perspective, since it does not possess ways of quantitatively measuring and interpreting the data, however at the same time it does provide us with a rich source of information that cannot be attained with quantitative methods. Nonetheless, the study could have benefited from using more than one methodology, for example, a Delphi study could have been conducted with experts from the field of Industry 4.0 and smart manufacturing, in order to reduce bias of our study.

We believe that future studies will make comparisons and eventually measure, for example, the impact of specific competencies on productivity, innovation etc. in 4.0 industry. Yet, the first identification of perceived future job profiles and competencies needs to be done. For Slovenia, this empirical study sheds light on what 4.0 industry needs.

\section{Literature}

Arsenijević, O., Trivan, D., Podbregar, I., \& Šprajc, P. (2017). Strategic aspect of knowledge management. Organizacija, 50(2), 163-176. http://doi.org/10.1515/orga-20170011

Bagnoli, C., Dal Mas, F., \& Massaro, M. (2019). The 4th Industrial Revolution: Business Models and Evidence from the Field. International Journal of E-Services and Mobile Applications (IJESMA), 11(3), 34-47. http://doi.org/10.4018/IJESMA.2019070103

Barth, M., Godemann, J., Rieckmann, M., \& Stoltenberg, U. (2007). Developing key competencies for sustainable development in higher education. International Journal of Sustainability in Higher Education, 8(4), 416-430. http://doi.org/10.1108/14676370710823582

Bertoncel, T., Erenda, I., \& Meško, M. (2018). Managerial early warning system as best practice for project selection at a Smart factory. Amfiteatru Economic, 20(49), 805819. http://doi.org/10.24818/EA/2018/49/805

Bilas, V., Franc, S., \& Arbanas, B. (2013). The impact of current economic crisis on the automotive industry. Ekonomska misao i praksa: časopis Sveučilista u Dubrovniku, 22(1), 299.

Boštjančič, E., Brečko, D., Zadel, A., \& Kamenik, M. F. (2011). Merjenje kompetenc: metoda ocenjevalnega centra $v$ teoriji in praksi [Measuring competencies: An assessment centre method in theory and practice]. Ljubljana: Planet GV.

Boyatzis, R. (1982). The Competent Manager. New York: EEUU Ed.

Brettel, M., Friederichsen, N., Keller, M., \& Rosenberg, M. (2014). How virtualization, decentralization and network building change the manufacturing landscape: An Industry 4.0 Perspective. International Journal of Mechanical, Industrial Science and Engineering, 8(1), 37-44.

Caelli, K., Ray, L., \& Mill, J. (2003). 'Clear as mud': toward greater clarity in generic qualitative research. International Journal of Qualitative Methods, 2(2), 1-13. https://doi.org/10.1177\%2F160940690300200201

Cooper, J., \& James, A. (2009). Challenges for database management in the internet of things. IETE Technical Review, 26(5), 320-329. http://doi.org/10.4103/0256-4602.55275

Creswell, J. W., Hanson, W. E., Clark Plano, V. L., \& Morales, A. (2007). Qualitative research designs: Selection and implementation. The Counselling Psychologist, 35(2), 236264. https://doi.org/10.1177/0011000006287390

Enke, J., Glass, R., Kreß, A., Hambach, J., Tisch, M., \& Metternich, J. (2018). Industrie 4.0-Competencies for a modern production system: A curriculum for learning factories. Procedia Manufacturing, 23, 267-272. https://doi.org/10.1016/j.promfg.2018.04.028

Erenda, I., Metelko, A., Roblek, V., \& Meško, M. (2018). The Leadership Competencies and Intuitive Decision-Making of Top and Middle Level Managers in the Automotive Industry. In Governing Business Systems (pp. 119-140). Springer, Cham. http://doi.org/10.1007/978-3-319-66036-3_7

Erol, S., Jäger, A., Hold, P., Ott, K., \& Sihn, W. (2016). Tangible Industry 4.0: a scenario-based approach to learning for the future of production. Procedia CIRP, 54, 13-18. 
https://doi.org/10.1016/j.procir.2016.03.162

Erpenbeck, J., \& Von Rosenstiel, L. 2007. Handbuch Kompetenzmessung: Erkennen, verstehen und bewerten von Kompetenzen in der betrieblichen, pädagogischen und psychologischen Praxis. Stuttgart: Schäffer-Poeschel Verlag.

Frank, E. (1991). The UK's Management Charter Initiative: The First Three Years. Journal of European Industrial Training, 15(6). http://doi.org/10.1108/03090599110142448

Galletta, A. (2013). Mastering the Semi-Structured Interview and Beyond: From Research Design to Analysis and Publication. New York; London: NYU Press.

Gilchrist, A. (2016). Introducing Industry 4.0. In Industry 4.0 (pp. 195-215). Apress, Berkeley, CA. http://doi.org/10.1007/978-1-4842-2047-4 2

Govindan, K., Cheng, T. C. E., Mishra, N., \& Shukla, N. (2018). Big data analytics and application for logistics and supply chain management. Transportation Research Part E: Logistics and Transportation Review, 114, 343349. https://doi.org/10.1016/j.tre.2018.03.011

Greengard, S. (2015). The internet of things. Cambridge, Massachusetts: MIT Press.

Hecklau, F., Galeitzke, M., Flachs, S., \& Kohl, H. (2016). Holistic approach for human resource management in Industry 4.0. Procedia CIRP, 54, 1-6. http://doi.org/10.1016/j.procir.2016.05.102

Hecklau, F., Orth, R., Kidschun, F., \& Kohl, H. (2017). Human resources management: Meta-study-analysis of future competences in Industry 4.0. In Proceedings of the International Conference on Intellectual Capital, Knowledge Management \& Organizational Learning (pp. 163174).

Hitpass, B., \& Astudillo, H. (2019). Editorial: Industry 4.0 challenges for business process management and electronic-commerce. Journal of Theoretical and Applied Electronic Commerce Research, I-III. https://doi.org/10.4067/S0718-18762019000100101

Hofmann, E., \& Rüsch, M. (2017). Industry 4.0 and the current status as well as future prospects on logistics. Computers in industry, 89, 23-34. https://doi.org/10.1016/j.compind.2017.04.002

Hungerland, F., Quitzau, J., Zuber, C., Ehrlich, L., Growitsch, C., Rische, M. C., ... \& Haß, H. J. (2015). The digital economy (No. 21e). Strategy 2030-Wealth and Life in the Next Generation. https://www.econstor.eu/handle/10419/121322

Imran, F., \& Kantola, J. (2018). Review of Industry 4.0 in the Light of Sociotechnical System Theory and Competence-Based View: A Future Research Agenda for the Evolute Approach. In International Conference on Applied Human Factors and Ergonomics (pp. 118-128). Springer, Cham. http://doi.org/10.1007/978-3-319-94709-9 12

Ivanov, D., Dolgui, A., Sokolov, B., Werner, F., \& Ivanova, M. (2016). A dynamic model and an algorithm for shortterm supply chain scheduling in the smart factory industry 4.0. International Journal of Production Research, 54(2), 386-402. http://doi.org/10.1080/00207543.2014.999958

Liu, D. (2019). Bloomberg NEF's country ranking reveals models of industrial digitalization. Retreived from https:// about.bnef.com/blog/bloombergnefs-country-ranking-reveals-models-industrial-digitalization/
Kache, F., \& Seuring, S. (2017). Challenges and opportunities of digital information at the intersection of Big Data Analytics and supply chain management. International Journal of Operations \& Production Management, 37(1), 10-36. http://doi.org/10.1108/IJOPM-02-2015-0078

Kagermann, H., Helbig, J., Hellinger, A., \& Wahlster, W. (2013). Recommendations for implementing the strategic initiative INDUSTRIE 4.0: Securing the future of German manufacturing industry; final report of the Industrie 4.0 Working Group. Forschungsunion.

Kane, G. C., Palmer, D., Phillips, A. N., \& Kiron, D. (2015). Is your business ready for a digital future?. MIT Sloan Management Review, 56(4), 37.

Kauffeld, S. (2006). Self-directed work groups and team competence. Journal of Occupational and Organizational Psychology, 79(1), 1-21. http://doi.org/10.1348/096317905X53237

Kauffeld, S. (2016). Nachhaltige Personalentwicklung und Weiterbildung. Berlin Heidelberg: Springer.

Kompetenzaufbau. 2016. Kompetenzentwicklungsstudie Industrie 4.0 - Acatech. Retrieved from Https://www. acatech.de/Projekt/kompetenzentwicklungsstudie-industrie-4-0/

Kotzab, H., Teller, C., Bourlakis, M., \& Wünsche, S. (2018). Key competences of logistics and SCM professionals-the lifelong learning perspective. Supply Chain Management: An International Journal, 23(1), 50-64. https://doi.org/10.1108/SCM-02-2017-0079

Kremer, D. (2014). Prozess-szenarien für die Industrie 4.0. Retrieved from https:/www.iao.fraunhofer.de/images/ iao-news/iao-news_oktober_2014.pdf

Lai, Y., Sun, H., \& Ren, J. (2018). Understanding the determinants of big data analytics (BDA) adoption in logistics and supply chain management: An empirical investigation. The International Journal of Logistics Management, 29(2), 676-703. https://doi.org/10.1108/IJLM-06-2017-0153

Lamut, U., \& Macur, M. (2012). Metodologija družboslovnega raziskovanja [Methodology of social science research]. Ljubljana: Vega.

Le Deist, F. D., \& Winterton, J. (2005). What is competence?. Human Resource Development International, 8(1), 27-46. https://doi.org/10.1080/1367886042000338227

Lee, J., Ardakani, H. D., Yang, S., \& Bagheri, B. (2015). Industrial big data analytics and cyber-physical systems for future maintenance \& service innovation. Procedia CIRP, 38, 3-7. https://doi.org/10.1016/j.procir.2015.08.026

Lee, J., Kao, H. A., \& Yang, S. (2014). Service innovation and smart analytics for industry 4.0 and big data environment. Procedia CIRP, 16, 3-8. https://doi.org/10.1016/j.procir.2014.02.001

Leoni, R. (2012). Workplace design, complementarities among work practices, and the formation of key competencies: Evidence from Italian employees. ILR Review, 65(2), 316-349. http://doi.org/10.1177/001979391206500206

Lorenz, M., Rüßmann, M., Strack, R., Lueth, K. L., \& Bolle, M. (2015). Man and machine in industry 4.0: How will technology transform the industrial workforce through 2025. The Boston Consulting Group. Retrieved from https://www.bcg.com/publications/2015/technology-business-transformation-engineered-products-infra- 
structure-man-machine-industry-4.aspx

Macurová, P., Ludvík, L., \& Žvakowa, M. (2017). The driving factors, risks and barriers of the industry 4.0 concept. Journal of Applied Economic Sciences, 12(7), 2003-2011. http://doi.org/10.3390/economies6030046

Markus, L., Cooper-Thomas, D. \& Allpress, N. (2005). Confounded by Competencies? New Zealand Journal of Psychology, 34; 117-126.

MarketAndMarkets (2017). Industry 4.0 market by technology (industrial robotics, cyber security, internet of things, 3D printing, advanced human-machine interface, big data, augmented reality \& virtual reality, artificial intelligence), vertical, region- global forecast to 2022. Market Research Report SE 5279. Retrieved from https://www. marketsandmarkets.com/Market-Reports/industry-4-market-102536746.html

McClelland, D. C. (1973). Testing for competence rather than for "intelligence". American Psychologist, 28(1), 1-14. https://doi.org/10.1037/h0034092

Mosconi, F. (2014). The New European Industrial Policy: Global Competitiveness and the Manufacturing Renaissance. London: Routledge.

Nader, M., Jameela, A. J., \& Jawhar, I. (2008). Middleware for robotics: A survey. IEEE Intl, editor, Robotics, Automation, and Mechatronics, 736-742. http://doi.org/10.1109/RAMECH.2008.4681485

Neuendorf, K. A. (2016). The Content Analysis Guidebook. Thousand Oaks: Sage.

Nippa, M., and Egeling, A. (2009). Kompetenzbedarfe im Kontext hybrider Wertschöpfung. Siegburg: Eul-Verlag.

Pecina, P. \& Sladek, P. (2017). Fourth industrial revolution and technical education. Proceeding of 11th International Conference on Technology, Education and Development (INTED), (pp. 2089-2093). http://dx.doi.org/10.21125/inted.2017.0621

Prifti L, Knigge M, Kienegger H, Krcmar H. (2017). A Competency Model for "Industrie 4.0" Employees, in Leimeister, J.M.; Brenner, W. (Hrsg.): Proceedings der 13. Internationalen Tagung Wirtschaftsinformatik (WI 2017), St. Gallen, p. 46-60.

Rychen, D. S., \& Salganik, L. H. (Eds.). (2003). Key competencies for a successful life and well-functioning society. Göttingen: Hogrefe \& Huber Publishing.

Rifkin, J. (1995). The end of work: The decline of the global labor force and the dawn of the post-market era. New York: GP Putnam's Sons.

Roblek, V., Meško M. \& Krapež A. (2016). A Complex View of Industry 4.0. Sage Open, 6(2), 1-12. http://doi.org/10.1177/2158244016653987

Sarvari, P. A., Ustundag, A., Cevikcan, E., Kaya, I., \& Cebi, S. (2018). Technology roadmap for Industry 4.0. In: Industry 4.0: Managing The Digital Transformation (pp. 95-103). Springer, Cham. http://doi.org/10.1007/978-3-319-57870-5_5

Segal, M. (2018). How automation is changing work: more robotics and artificial intelligence in the workplace doesn't have to destroy your job. Nature, 563: S132-135. Retrieved from https://www.nature.com/articles/d41586018-07501-y

Slovenska avtomobilska industrija vedno bolj robotizira$n a$ [The Slovenian automotive industry is increasingly robotic] (2019). Retrieved from https://www.rtvslo.si/ gospodarstvo/slovenska-avtomobilska-industrija-vedno-bolj-robotizirana/470137

Spencer, L., Spencer, S. (1993). Competence at Work: Model for Superior Performance. New York: John Wiley \& Sons.

Straka, G. A. 2004. Measurement and Evaluation of Competence. Retrieved from http://www.cedefop.europa.eu/ files/BgR1_Straka.pdf.

Šimek, D., \& Šperka, R. (2019). How Robot/human Orchestration Can Help in an HR Department: A Case Study From a Pilot Implementation. Organizacija, 52(3). DOI: 10.2478/orga-2019-0013

Vacek, J. (2016). Socio-economic aspects of Industry 4.0. In Innovation Management, Entrepreneurship and Corporate Sustainability (IMECS 2016) (pp. 731-741). Prague: Vysoká škola ekonomická v Praze.

Vogel-Heuser, B., \& Hess, D. (2016). Guest editorial industry 4.0-prerequisites and visions. IEEE Transactions on Automation Science and Engineering, 13(2), 411-413. http://doi.org/10.1109/TASE.2016.2523639

Vogrinc, J. (2008). Kvalitativno raziskovanje na pedagoškem področju [Qualitative research in the pedagogical field] Ljubljana: Univerza v Ljubljani, Pedagoška fakulteta.

Wood, L. (2018). Global Industry 4.0 Market \& Technologies 2018-2023: Market is Expected to Reach \$1 Trillion by the Early 2030s. Retrieved from https://www.globenewswire.com/news-release/2018/05/08/1498224/0/en/Global-Industry-4-0-Market-Technologies-2018-2023-Market-is-Expected-to-Reach-1-Trillion-by-the-Early-2030s. html

World Economic Forum. (2018). The world is changing. Here's how companies must adapt. Retrieved from https:// www.weforum.org/agenda/2018/01/the-world-is-changing-here-s-how-companies-must-adapt

Zhang, J., Yao, X., Zhou, J., Jiang, J., \& Chen, X. (2017). Self-organizing manufacturing: Current status and prospect for Industry 4.0. In 2017 th International Conference on Enterprise Systems (ES) (pp. 319-326). IEEE.

Zinn, B. (2015). Conditional variables of 'Ausbildung 4.0'Vocational education for the future. Journal of Technical Education (JOTED), 3(2), 1-9.

Ženko, Z., Mulej, M., \& Potočan, V. (2017). Knowledge-cum-values Management belongs to the Way out from Global Crisis. Business Systems Research, 8(1), 113123. http://doi.org/10.1515/bsrj-2017-0009 
Andrej Jerman, is a doctoral student at the Faculty of Management at the University of Primorska. He graduated from the Faculty of Commercial and Business Sciences in Celje, he received his Master degree at the Faculty of Management of the University of Primorska. He is employed at Ljubljanski potniški promet in Ljubljana. His research interests include the field of management, healthy lifestyle and professional drivers. He has already published some scientific articles on this subject.

Andrej Bertoncelj, is Full Professor of Management at the Faculty of Management, University of Primorska. $\mathrm{He}$ has extensive international experience in general management with particular focus on M\&A and strategic alliances. His scientific papers were published in many international journals and his book on mergers and acquisitions is translated in three foreign languages. His research interests include growth strategy, globalisation trends, mergers and acquisitions and post-merger integration. He received a silver award of recognition from Slovene Chamber of Commerce for co-development of the business model of four evolutionary phases.

Gandolfo Dominici, is Associate Professor of Marketing at the University of Palermo, Faculty of Economics, Department SEAS. He is also co-founder, scientific director and vice-president of Business Systems Laboratory (B.S.Lab) and Directors Board Member of the World Organisations Systems and Cybernetics (WOSC). He is editor in chief of Kybernetes,
International Journal of Market and Business Systems, International Journal of Electronic Marketing and Retailing, and International Journal of Economics and Business Modelling. His scientific papers were published in many international journals.

Mirjana Pejić Bach, is a Full Professor at the Department of Informatics at the Faculty of Economics \& Business. She graduated at the Faculty of Economics \& Business - University of Zagreb, where she also received her Ph.D. degree in Business, submitting a thesis on "System Dynamics Applications in Business Modelling" in 2003. She is the recipient of the Emerald Literati Network Awards for Excellence 2013 for the paper Influence of strategic approach to BPM on financial and non-financial performance published in Baltic Journal of Management. Mirjana was also educated at MIT Sloan School of Management in the field of System Dynamics Modelling, and at OliviaGroup in the field of data mining. She participates in number of EU FP7 projects, and is an Expert for Horizon 2020.

Anita Trnavčević, former dean of the Faculty of Management, University of Primorska, 2010-2014, is a Full professor in Management in education and Associate Professor in Research Methodology in Social Science. She examines education policies and marketing of education. As a carrier and researcher, she has been involved in numerous national and international research projects. She is an advocate for sustainable growth and development and for quality and responsible public education. 